\title{
Finding Ownership Structure in the Mining Industry by Using Islamic According Perspective
}

\author{
Andi Sri Wahyuni ${ }^{1}$, Agung Juliarto ${ }^{2}$, Anis Chariri ${ }^{3}$ \\ \{andisriwahyuni@poliupg.ac.id¹,juliarto432@gmail.com², anis_chariri@live.undip.ac.id ${ }^{3}$ \} \\ Accounting Department, Politeknik Negeri Ujung Pandang, Makassar, Indonesia ${ }^{1}$ \\ Accounting Department, Diponegoro University, Semarang, Indonesia ${ }^{2,3}$
}

\begin{abstract}
This study is intended to find the fair distribution of ownership structure in extractive industries. The analysis was conducted on financial reporting documentation published by PT Freeport Indonesia - via its official online website- by using a critical perspective approach. As a knife to criticize the existing system, the doctrine of Islamic Economics is used. From this analysis, we find that the three owners of mining excavations obtained are the government as state managers, paid in the form of state taxes; the weak and oppressed communities, paid in the form of zakat; and the owner of the mine excavations themselves who have done work to obtain it.
\end{abstract}

Keywords: Islamic accounting, the mining excavation businesses, the ownership structure.

\section{Introduction}

The mining industry is a kind of natural mineral asset, which plays a critical role in influencing the livelihoods of the people [1]. However, contrary to this fact, state revenue is not directly proportional to the welfare obtained by the community around the excavated area or where the company operates. Even welfare for the scale of the country, when compared to the total profits generated, is still far from "proportional" in comparison to dredged natural resources. Mining activities do not bring prosperity, but in fact, they bring misery to the point of causing environmental damage, ranging from the loss of biodiversity to the formation of acid mine drainage [2].

In May 2013, the PT Freeport tunnel collapsed and claimed 38 victims (28 died). They are the workers of the company. The tunnel is part of PT Freeport's training room (beritaburuhindonesia.com). Phakathi also claims that this issue apparently does not only occur in South Africa but also in Indonesia, where workers and miners are neglected from adequate facilities in their work processes at the company [3]. It is totally supported by this argument: "indonesian's low concern for labors issues" [4].

Then the concept of Islamic accounting came, not merely as a counter-hegemony of the system that has been established today, but as rahmatan lil'alamin, which means "to always rest on the value of justice, both for all workers, also for the universe." The presence of an established form of Islamic accounting still rests on harmonization that is based on conventional accounting [5].

Kamla states explicitly that Islamic accounting, 
“... is further exacerbated by uncritical emulation and embracing of conventional accounting operations and standards by so-called Islamic ones... [that is why] the paper also attempts to identify ways forward for Islamic banking and accounting research to realize more emancipatory praxis." [6]

Kamla's research is an effort to ignite the presence of liberating Islamic accounting free from the confines of capitalist-faced accounting. Thus, Islamic accounting needs to be 'discovered,' by departing from its independent concept, sourced from various fragments of the Qur'an and Hadith.

Based on these reasons, this research was carried out to answer two main questions: what exactly is the fair distribution of rights to mining products, and how does Islamic accounting become a solution by offering a fair accounting system? In this case, a fair alternative for all stakeholders, either directly or indirectly related to the company's operational activities.

\section{Research Methodology}

This study was designed using a qualitative approach to answer the two research questions above. The model that can answer the research problem is the critical theory model "an alternative perspective of the role of accounting" [7]. This research will use PT Freeport's corporate financial reporting as an example of the superstructure to analyze the intended injustice. Deconstruction efforts are carried out after the critical analysis process of financial reporting is completed.

Because this study uses a critical perspective, according to Deegan, researchers will always view accounting, not as something neutral and value-free [7], but rather 'emancipatory' [8]. There is an ideal concept that is carried by researchers when dealing with problems encountered in the field. Therefore, the critical approach is scientific work that is in the path of das sollen (there should be), not just research with the results of das sein (what is there).

However, the efforts of this model do not only cover identification and critical analysis but try to change dominance. Therefore, a theory-driven model is needed, or in simpler terms [9], researchers should start from a clear foundation to see reality. Islamic accounting and its theories, as a part of the doctrine that researchers believe, is chosen as a tool that serves as a guide in the process of analyzing and deconstructing the object of this study.

The study was done in a period of seven months. The assumption of the adequacy of the seven months because the qualitative research time setting should be more than three months to minimize misinterpretation and bias during the research process [10].

Meanwhile, as stated earlier, the data used in this study was obtained from a financial reporting documentation published by PT Freeport via its official online website, www.ptfi.co.id.

Sources of official document data can be divided into two, namely, internal and external documents [11]. The financial reporting documentation is classified as an internal document. External documents include books, articles, and other archives that are officially published by the company. 


\section{Result and Discussion}

PT Freeport is the third-largest mining company in the world that has subsidiaries in developing countries, including Indonesia. McMoran, the parent company of PT Freeport, has opened several subsidiaries in Africa, South America, and Indonesia. These countries are rich in important natural resources. Amid its limitations in processing these natural resources, giant companies from America came up with smart technology and human resources and offered processing cooperation. But what happened behind the contract of cooperation status?

The Comprehensive Income Statement released by PT Freeport through its official website explicitly states the amount of operating profit obtained from PT Freeport's operations in just three months (as of September 2014). The figure of 434 million dollars, when converted, makes a total value of Rp 5.939.290.000.000. The total value, according to the FASB definition (1991) in SFAC No. 1 paragraph 43, is a measure used by stakeholders to obtain information related to company performance.

Based on references from the 2014 Freeport-McMoran Consolidated Annual Report, more complete data can be obtained. Profits from PT Freeport's production in one year reached a total of 817 million US dollars. This figure is far greater when converted into rupiahs. The question then is, how much does Indonesia get from the performance of the Freeport company?

"Indonesia mining includes PT-FI's Grasberg minerals district, one of the world's largest copper and gold deposits, in Papua, Indonesia. We own 90.64 percent of PTFI, including 9.36 percent owned through our wholly-owned subsidiary, PT Indocopper Investama." (p.50)

The excerpt above was copied from the Annual Report released ${ }^{6}$ by Freeport-McMoran management. The report implicitly explains that the Indonesian government received the remaining shares after PT Freeport's $90.64 \%$ stake. As for the richness of Indonesians natural resources, the term "remains" is more appropriate, considering the composition that is owned by the foreign company. Sadly, especially when recalling the "holy book" sovereignty of the Indonesian state in article 33 paragraph 3 of the 1945 Constitution, "earth, water, and all the natural resources contained therein are controlled by the state, and used as much as possible for the prosperity of the people."

The impact of this minority ownership is felt everywhere. Various research results in the field of finance and capital market prove this. They are starting from the risk of losing control to the expropriation of minority shareholders [12, 13, 14, 15]. Minority shareholdings owned by the government have an impact on the weak control over mining resources in Grasberg, Papua.

The government is not strict in taking action against Freeport, although Freeport clearly does not commit to several of its agreements. The soft nature of the government is a reflection of its attitude towards foreign companies that want and have implemented contracts in Indonesia. The government created a world where corporate wealth absorbs the wealth of the country, and business people are ranked higher than the government. This is a sign of what's known as a 'Quiet Takeover' [16].

From the overall inequality conditions that have been described, the concept of equitable distribution of mining products needs to be established. Islamic accounting, as a system of measurement, recording, and reporting, is the answer to this, and as such, it is necessary to become 'discovered'. 


\subsection{Special Form of Ownership of Mining Control}

In the case of mining, the form of ownership of companies in Indonesia resembles that of a capitalistic state. While in Islamic economic doctrine, ownership of mining excavation is owned by the state [17]. The government, as the representative and leader of a community, is the holder of ownership rights to the natural resources.

The faqihs generally divide mineral materials into two categories: azh zhâhir (open or visible) and al bâthin (hidden) [17]. Azh zhâhir minerals are substances that do not require additional effort and processes to reach their final form, and their mineral substances appear naturally. Examples of this type of mineral are salt and oil. Oil minerals can be found in its actual state. No further process is needed to convert it into the oil - although a great effort is needed to explore and purify the oil. The case is different with al batthin minerals. In fiqh, this means any mineral that requires further effort and processing so that its mineral properties appear. Examples of this type of mineral are gold and iron. Such substances cannot be obtained from the bowels of the earth in their perfect state but require great effort to convert it to tradeable gold and iron.

So, the open or closed nature of a mineral in fiqh terms relates to the nature of a material or the degree of perfection of its condition, not to its location or proximity to the surface or depth in the earth since a mine can be opened, but it is in the depths of the earth which require a great amount of effort to obtain it [17]. It is important to distinguish the two types of mineral material based on these properties. Differences in character, whether they are closed or open, affect the distribution of ownership over them. The laws in Islamic economic doctrine differ between the two.

For this research, due to PT Freeport Indonesia being used as a mirror to analyze the distribution system of mining ownership, the mining materials processed by the company will also be described in the form of ownership in the Islamic economic doctrine. This is done to fulfill the requirements of relevance and coherence of scientific research [18].

Based on the latest annual report (2014) released by Freeport-McMoran, which is also an example of the object for critical analysis of this study, PT Freeport Indonesia produces Copper $(\mathrm{Cu})$ and Gold $(\mathrm{Au})$. From the explanation provided by Ash-Sadr, also rewritten by Fauzani in his research related to the distribution of the preproduction of mineral resources, copper and gold are grouped into types of hidden minerals (al bâathin) [17, 19]. Thus, the distribution that will be elaborated based on the concept of Islamic economic doctrine only focuses on these hidden mineral resources because gold and copper (mines that are processed by Freeport) are grouped in the mining material.

In the theory of the distribution of hidden mineral preproduction, minerals are divided into two more groups $[17,19]$. First, hidden minerals that are close to the surface of the earth, and second, those are found in the depths of the earth.

In the writings of Freeport's management, which is one of its mining documentations books, mining activities are also classified into two. The following quote explains this:

"PT Freeport Indonesia is currently mining from the Grasberg Open Mine (Porphyry $\mathrm{Cu} / \mathrm{Au}$ ) and the DOZ Underground Mine from the EESS (Eart Ertsberg Skarn System) ore deposit system with the main commodity being copper with the associated commodity being gold...." [20].

Thus, hidden minerals that are close to the surface of the earth can be considered the same as the term used by Freeport, an Open Mine, and hidden minerals that are buried are the same as an Underground Mine. 
Hidden minerals close to the surface of the earth are shared with the community $[17,19]$. Because of the status of shared property - where authority is held by the government and private ownership is not permitted - individuals are only allowed to take advantage of these minerals as long as they do not monopolize and exploit without limits.

Islam does not allow a monopoly ${ }^{8}$ of minerals by anyone. Syâriah only allows individuals to take these mineral materials to cover their own needs [17]. According to the analysis of Fauzani, this follows the ideals of Islam to provide welfare within the framework of justice [19]. If an individual is free to use minerals without limits, then a wealth gap of natural resources will certainly occur.

Thus the rules of ownership of hidden mineral resources close to the surface of the earth (open-pit) based on Islamic economic doctrine are as follows: ownership rights of open-pit mineral resources are the community's shared by the community and controlled by the government. Therefore, in the distribution of the preproduction of natural resources, absolute individual ownership is not recognized, which undoubtedly leads to exploitation. The only type of ownership is state ownership.

When someone who finds a source of mining and reclaims it (makes an effort to get the source of the mine in the depths of the earth), then the individual has the right to use the source for excavation. That person has an exclusive right to prohibit others from interfering with the process of excavating and using the resources found in the quarry. However, when the individual leaves the excavation source due to natural causes, the excavation source becomes closed, and others have the right to take advantage of the mine in the same place [17]. This happens because the work that has been poured out by the first individual has been lost. Opportunities that were created to make the mine usable have disappeared.

Just like an open-pit mine, the hidden mineral ownership rights are still shared and held by the state. Syâriah only allows each individual to extract hidden minerals from the natural resources the person has worked on by carrying out the process of discovery and excavation, and he or she can take they need without harming others $[17,19]$.

The difference between an open-pit mine and an underground mine is that in an underground mine, it is likely that people who find a source of mining through excavation will recognize it as private property. This is based on equalizing the treatment of land reclamation. The faqihs consider that by carrying out the process of excavating at a mined source, it provides a way to gain dominance and control [19]. However, it is necessary to emphasize limitations. Mining ownership does not extend to the depths of the earth and its sources and roots. Consequently, only excavated minerals are included in possession of the inventor as well as the digger. In fiqh terms, the portion outside the boundary is called a mining area for others.

The distribution of ownership rights to a source of underground mining excavation is narrow and limited. The second person can excavate in the place that has been found and excavated by the first person because the latter is considered to have no mineral resources. This further confirms that Islam does not recognize public ownership, which can cause social inequality. In this case, it is true that Fauzani concluded about his reading of Islamic doctrine at the source of the mine, i.e., a person or a handful of people are not entitled to the privilege of the state to exploit it without involving the people at large [19].

\subsection{Work: The Basis for Obtaining Ownership Rights Over A Mine}

Wealth owned by Muslims must be obtained in the right way according to the framework outlined in Islam because a person will be held accountable ${ }^{9}$ for his or her enjoyment from 
ownership in the afterlife. In the preproduction theory, natural wealth can only be obtained through exclusive rights from the results of work activity [17].

This theory recognizes the existence of two economic activities, namely utilization and monopolization (control). However, for natural resources in the form of land, mining, and water, the only economic activity recognized is the first: utilization. Meanwhile, the second activity is only a manifestation of power and domination, not economic activity in the form of natural resource utilization. Therefore, in Shari'a point of view, power, and ability to control are insufficient to be the basis of acquiring special rights [17]. Just as Freeport-McMoran's shareholders who have the proceeds from the quarry due to their strength and dominance in the form of shares, this, in sharia's view, is not justified.

\subsection{Various Factors of Production}

As explained earlier, mining companies, supported by the assumptions of the doctrine of capitalism, put all factors of production on an equal footing. Workers and/or laborers are paid wages for work provided in the production process. Investors (shareholders) receive ${ }^{10}$ dividends in return for providing funds. Both workers and capital, in the doctrine of capitalism, are regarded as agents of production and power in the process of production.

Islam rejects this view and is fundamentally different from the concept of capitalism. Islam puts each factor of production in its place. The general theory of Islamic economics about postproduction distribution views that the product of production - in the form of natural raw materials - belongs completely to the worker, while the various instruments and means of production used by workers are only facilities that help them in achieving the objectives of production activities. Consequently, if the facilities used by the worker are not his, the worker is obliged to pay compensation for the equipment that has been used. There is also a rental fee paid by the worker to the lessee, not representing the share of the equipment used in his capacity as a factor of production. The money paid is only compensation for the use of tools [17].

Thus, in Islamic theory regarding post-production distribution, workers are the real owners of the products produced from the raw materials in the form of mining. The capital owner does not become the owner of the minerals mined by the workers, as is permissible in the capitalist doctrine.

Material factors, such as machinery and capital, have no part of the product that is produced from the mining process. The portion of material facilities involved in production activities is only in the form of compensation. Material means do not symbolize equality with human labor. Material means are only servants, not partners. This is in line with the nature of human creation, which God places as the noblest of all creatures.

Therefore, in the Freeport corporate wage system that includes wages as a cost component, it is tantamount to placing human labor as a means of production. Therefore, human labor is considered to be the same as a burden that reduces company profits. This concept is only permitted by the doctrine of capitalism in which humans are seen as equivalent to mechanical devices.

\subsection{The Phenomenon of Constancy}

The phenomenon of constancy is the principle of Islamic economic doctrine built on the foundation of a spirit of respect for work [17]. If a mining worker discovers and extracts a source from a mine, he is entitled to the results of his work (as has been clear in the 
preproduction distribution concept discussed earlier). If then the owner of the mining product hands over the results of his mining excavation to someone to process the mine into tradeable copper, then the results in the form of tradeable copper will remain the property of the first person. This is what is meant by the principle of constancy. A person does not lose his right to material resources that he has just because the product has changed form. Islam does not violate the ownership rights of someone who is devoted to finding and exploring a source of mining. Ownership of the basic mining material does not necessarily disappear simply because someone else adds work to the material, because "property is strongly protected in Islamic law." [21]

Then, for the work of people who have changed the basic ingredients of the mine into tradeable copper, the owner must pay wages as compensation. Thus, if someone adds work to the source of production of raw materials that have been subject to ownership rights by him (someone else already has it), then that person cannot be the new owner of the product he is processing.

Islam, in this position, views the work of the second person as not automatically making him the owner of the copper. This is because substantively, the copper is still owned by the first person. Although the basic ingredients of the mine have changed, the rights of the first person will not be harmed only because someone else helped him change the basic shape of his product. Regarding rights that are preserved and sustained, Muhammad sallallahu 'alayhi wasallam in his farewell sermon said that" indeed your blood, your treasure, and your honor are preserved between your neighbor as preserved today, this month and this country." (H.R. Bukhari and Muslim)

\subsection{Rules About Compensation}

It has been understood that when work is devoted to a mine that does not belong to someone else, the Islamic theory regarding postproduction distribution bestows all the wealth generated to the workers. While material factors used as worker aides in carrying out production activities only receive compensation from the worker. The means of production are not equal, and therefore do not share the results with workers [17].

Furthermore, if work is devoted to a mine that is already owned by someone else (it has been discovered and excavated so that it comes out of the bowels of the earth), then according to Islamic theory of postproduction distribution, the ownership of raw materials stays with the original owner. Work and all production activities, in changing raw materials, have no part in the commodities produced.

Workers who help in the production process are entitled to ask for money as a form of compensation for the work done. Meanwhile, tenants whose tools are used by miners get compensation called ujrah (compensation for services, and wages).

The machine was exchanged for compensation for rent simply because the machine had depreciated in the production process. Depreciation meaning the reduction of a machine's value [22] and age [23] is what the owner pays to the lessee as compensation in the form of rent or ujrah fees [24].

The machines used in the mines are not formed from nature or created by themselves. Therefore, the machine contains the elements of work derived from the materials. It is the work of converting the materials of the machine into a machine, and therefore the machine actually contains labor that is not directly stored. After the machine is formed, the work inside is still saved. Only after the machine is used for the production process does its value eventually decrease. So, in fact, both machines and people devote work to production. Only 
the working forms of the two are different. Humans devote their work in the form of direct labor, and the means of production contribute work that is still stored. Because both of them contribute to the process of changing the form of mining material to a newer form, they are both entitled to compensation from the mine owner. This shows the consistency of principles in Islamic economic doctrine that work is the basis of every acquisition and benefit of production.

From this, it also shows the reasons why Freeport shareholders who do not do direct work are not entitled to mining products in Papua. Even if the shareholders give up capital for the production process, based on the concept of compensation, the capital is only entitled to receive compensation in the form of rental fees. However, funds (capital) that increase in value without being based on their work (only based on the risk borne by shareholders) are also not recognized in Islam.

In conclusion, if the shareholders buy and/or finance processing and production equipment, then the rights obtained by the workers are limited to rental fees. They have no right to be an owner.

\subsection{Deconstruction of the Ownership Structure in Financial Statements}

The injustice that occurs in the process of sharing the results of excavation, based on the results of critical analysis, becomes an important finding in this research. Accounting itself has taken part by becoming a means for recording and recognizing ownership rights over the source of mining excavations. Therefore, Islamic accounting is used as an alternative in carrying out economic activities of the community with which the value of justice can be realized.

The rotation of the benefits from the exploration of the Freeport mine resources mostly revolves around the majority shareholders who buy shares through the New York Stock Exchange is contrary to God's mandate, "so that the treasure should not only circulate among rich people ... (Qur'an, 59: 7).

Three owners are entitled to mining excavations obtained by one or several individuals. First, the government. This is because the government is the representative of the people who manage a country and is entrusted with the regulation of the distribution of wealth for the fulfillment of the rights of every citizen. In carrying out its duties, the government requires operational costs and funds for the development of various policies. The funds are taken from the State Budget (APBN), which is prepared and renewed annually. APBN comes from various types of income sources, one of which is tax revenue. Every activity of extracting and utilizing the yields of excavation is required to pay a sum to the state in the form of tax. The second owner is weak and oppressed. The owner is entitled to any wealth obtained by people who do work and get compensated for that work. In the Islamic concept, in every asset obtained by each individual, there are rights of people in need. "And on their property, there is a right for the poor who ask and the poor who do not get a share." (Qur'an 51: 19) The third owner, of course, is the workers themselves. The workers in this regard are those who do the work directly to extract minerals from the bowels of the earth. The means of production used by workers are rewarded by receiving rent payments, which is a burden on production and reduces income at the same time. Symbolically, the following figure presents the ownership forms of the three owners of mining excavations based on Islamic economic doctrine: 


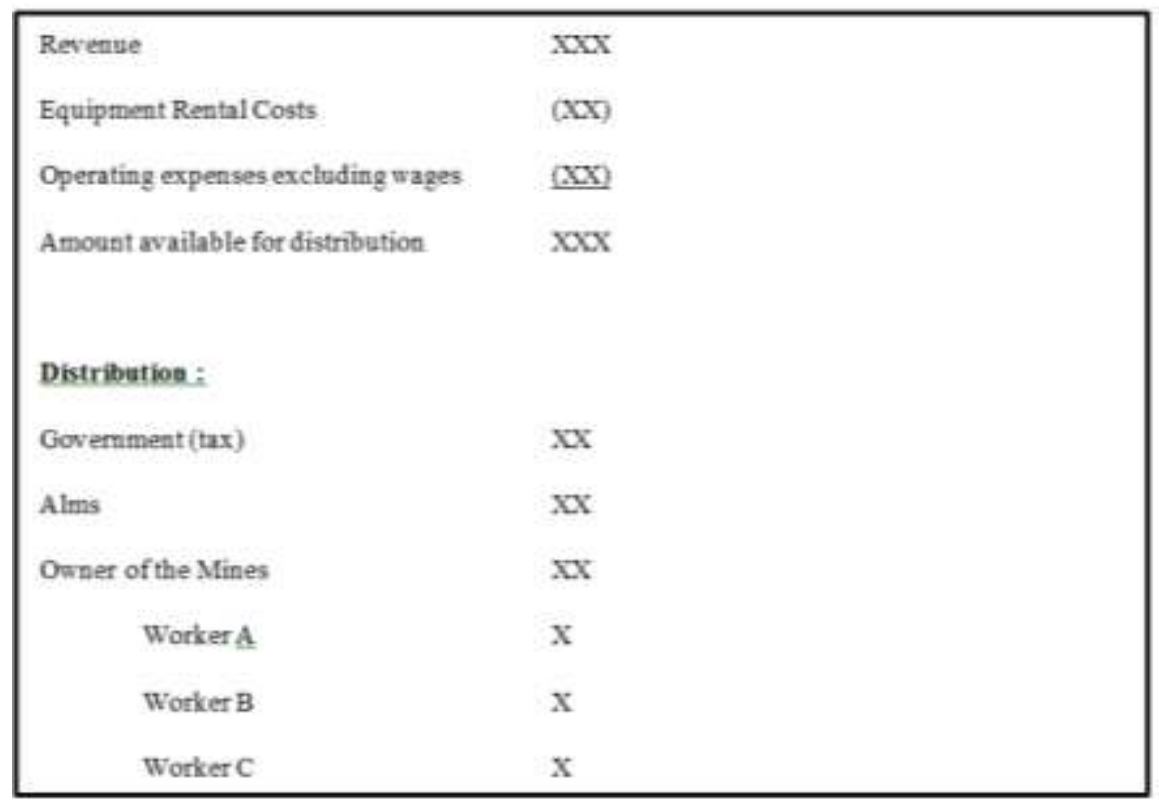

Fig. 1. The Form of Mining Product Distribution Based On Islamic Economic Doctrine

Figure 1 also explicitly states that the owners of capital do not have rights to the results of the mining excavation. If the investor contributes capital in the form of machines for the production process, then the investor is only entitled to the cost of leasing the machine.

\section{Conclusion}

From the results of the analysis, the distribution of the mining excavations yields in the mining company - in this case, PT Freeport Indonesia - is unfair. The owners of the mining excavation, namely the shareholders who get receive dividends, do not do direct work in the process of excavation and production. Therefore, shareholders do not have the rights to the excavation. The system of use is unfair and incorrect based on Islamic economic (accounting) concepts and doctrines.

Based on similar literal meanings, hidden minerals that are close to the surface of the earth are the same as 'open mining' in mining companies, and hidden minerals are the same as the term 'underground mining.' According to Shariah, the two types of mining, as long as they are still in the bowels of the earth or attached to the earth, are only owned by the state. This state ownership means that the source of the mining excavation belongs to the community in the country concerned, whose authority is held by the government. Therefore, people are allowed to take advantage of it to fulfill their needs but not monopolize and exploit without limits.

Communities, both in individual and group work, can benefit from natural resources in the form of mining materials by carrying out the excavation process. The process requires 
workers to have exclusive rights to it. In the Islamic accounting doctrine, income is based on work, both direct labor and stored labor.

The three owners of mining excavations obtained, both individuals and groups, are the government as state managers, paid in the form of state taxes; the weak and oppressed communities, paid in the form of zakat; and the owner of the mine excavations themselves who has done work to obtain it.

This study also has limitations that serve as an opportunity for the development of Islamic accounting in the future. The limitations and suggestions for future research are as follows:

1. The concept of the ownership structure comes from the concept of Islamic economics, which has been studied and researched by Ash-Shadr in his book that deals with Islamic economics comprehensively [17]. However, Ash-Sadr openly acknowledges that the research process in finding an ideal Islamic economic concept, apart from of course derived from the Qur'an and Hadith, is also taken from the author's ijtihad. In the process of ijtihad, Ash-Shadr acknowledged that what was produced in his book could not be decided in a final manner - that this is the true form of the Islamic economic doctrine (system) because, in ijtihad, mistakes can occur. Therefore, it is possible for the mujtahid to put forward a different form, and therefore, the derivative in the form of the ownership structure concept will also be different.

2. This study has limited observations. The alternatives offered in this study are still in the form of concepts. The elaborations which are then revealed in the applicative stage require further research. With further research, it is hoped that it can become material for the formulation of more complex forms of financial statements under the current condition of mining companies.

3. As a suggestion for further research, this research is still in a form that is thick with concepts, and therefore it is important to conduct further research to get to the technical level. To realize the contribution of research on both a theoretical and practical level requires a variety of multi-disciplinary scientific approaches in an integrative manner. From this research, like the concept of critical research, is not free of criticism. This research opens space for the process of finding the ideal concept in the future and is expected to foster new hopes for the realization of the concept of Islamic accounting, which is tailed from the objectives of Islam as rahmatan lil'alamin.

\section{References}

[1] Agustinne.: Perbandingan Standar Akuntansi atas Pertambangan Batubara antara FASB, IFRS, dan PSAK. Media Bisnis, Vol. 5 (3), pp. 183-199 (2013).

[2] Directorate of Mineral Resources and Mining, Republic of Indonesia. Mengatasi Tumpang Tindih antara Lahan Pertambangan dan Kehutanan.

[3] Phakathi, S. T.: "'Getting on" and "getting by" Underground", Gold Miners' Informal Working Practice of Making a Plan (Planisa)". Journal of Organizational Ethnography. Vol. 2 (2), pp. 126149 (2013).

[4] Cahaya, F. R., et. al.: "Indonesia's Low Concern for Labor Issues". Social Responsibility Journal, Vol. 8 (1), pp. 114-132 (2012).

[5] Hamid, S., Russell, C. and Clarke, F.: Religion: a Confounding Cultural Element in the International Harmonization of Accounting?. Abacus.Vol. 29 (2), pp. 131-148 (1993).

[6] Kamla, R.: Critical Insights into Contemporary Islamic Accounting. Critical Perspective on Accounting. Vol. 20 (8), pp. 921-932 (2009).

[7] Deegan, C.: Financial Accounting Theory. Australia: McGraw-Hill (2007). 
[8] Triyuwono, I.: Akuntansi Syariah; Perspektif, Metodologi, dan Teori. Jakarta: Pustaka Pelajar (2012).

[9] Searchy, D.L. and Mentzer, J.T.: A Framework for Conducting and Evaluating Research.: Journal of Accounting Literature, Vol. 22, pp. 130-167 (2003).

[10] Creswell, J.W. and Miller D.L.: Determining Validity in Qualitative Inquiry. Theory Into Practice. Vol. 39 (3), pp. 124-130 (2000).

[11] Moloeng, L.J.: Metodologi Penelitian Kualitatif: Edisi Revisi. Bandung: Rosdakarya (2014).

[12] Col, B. and Errunza, V.: Corporate Governance and State Expropriation Risk. Corporate Governance and State Expropriation Risk. Vol. 33, pp. 71-84 (2015).

[13] Caesari, A. D.: Expropriation of Minority Shareholders and Payout Policy. The British Accounting Revie. Vol. 44 (4) pp. 207-220 (2012).

[14] Kim, K.A., Kitsabunnarat-Chatjuthamard, P. and Nofsinger, J.R.: Large Shareholders, Board Independence, and Minority Shareholder Rights: Evidence from Europe. Journal of Corporate Finance. Vol. 13 (5), pp. 859-880 (2007).

[15] Santiago-Castro, M. and Brown, C.: Ownership Structure and Minority Rights: A Latin American View. Journal of Economics and Business, Vol. 59, No. 5, pp. 430-442 (2007).

[16] Hertz, N.: Perampok Negara: Kuasa Kapitalisme Global dan Matinya Demokrasi, translated by Mustafi, M. Yogyakarta: Alenia (2005).

[17] Ash-Shadr, M. B.: Buku Induk Ekonomi Islam: 'Iqtishaduna'. Translated by Yudi. Jakarta: Zahra Publishing House (2008).

[18] Chariri, A. The Dynamics of Financial Reporting Practice in an Indonesian Company: Reflection of Javanese Views on an Ethical Social Relationship. Jerman: VDM Verlag Dr. Müller (2006).

[19] Fauzani.: Keadilan Distribusi Praproduksi (Studi Pemikiran Muhammad Bāqir al-Şadr tentang Sumber Daya Mineral. School of Graduate Universitas Islam Negeri (UIN) Syarif Hidayatullah Jakarta (2010).

[20] Mahler, A and Sabirin, N.: Dari Grasberg sampai Amamapare: Proses Penambangan Tembaga \& Emas Mulai Hulu hingga Hilir. Jakarta: Gramedia Pustaka Utama (2008).

[21] Al-Kashif, A. E-R. M.: Shari'ah's Normative Framework as to Financial Crime and Abuse. Journal of Financial Crime. Vol. 16, No. 1, pp. 86-96 (2009).

[22] Baum, A. and Devaney, S.: Depreciation, Income Distribution and the UK REIT". Journal of Property Investment \& Finance. Vol. 26 (3), pp. 195-209 (2008).

[23] Liapis, K. J. and Kantianis, D.D.: Depreciation Methods and Life Cycle Costing (LCC) Methodology". Procedia Economics and Finance.Vol. 19, pp. 314-324 (2015).

[24] Oseni, U.: Towards Restructuring the Legal Framework for Payment System in International Islamic Trade Finance. Journal of International Trade Law and Policy. Vol. 12 (2), pp. 108-129 (2013). 